\title{
Immunopathogenesis of Human T-Cell Leukemia Virus Type-1-Associated Myelopathy/Tropical Spastic Paraparesis: Recent Perspectives
}

\author{
Mineki Saito ${ }^{1}$ and Charles R. M. Bangham ${ }^{2}$ \\ ${ }^{1}$ Department of Immunology, Graduate School of Medicine, University of the Ryukyus, 207 Uehara, Okinawa 903-0215, Japan \\ ${ }^{2}$ Department of Immunology, Wright-Fleming Institute, Imperial College London, Norfolk Place, London W2 1PG, UK
}

Correspondence should be addressed to Mineki Saito, mineki@med.u-ryukyu.ac.jp

Received 1 August 2011; Revised 30 September 2011; Accepted 9 October 2011

Academic Editor: Pooja Jain

Copyright ( $) 2012$ M. Saito and C. R. M. Bangham. This is an open access article distributed under the Creative Commons Attribution License, which permits unrestricted use, distribution, and reproduction in any medium, provided the original work is properly cited.

\begin{abstract}
Human T-cell leukemia virus type-1 (HTLV-1) is a replication-competent human retrovirus associated with two distinct types of disease only in a minority of infected individuals: the malignancy known as adult T-cell leukemia (ATL) and a chronic inflammatory central nervous system disease HTLV-1-associated myelopathy/tropical spastic paraparesis (HAM/TSP). HAM/TSP is a chronic progressive myelopathy characterized by spastic paraparesis, sphincter dysfunction, and mild sensory disturbance in the lower extremities. Although the factors that cause these different manifestations of HTLV-1 infection are not fully understood, accumulating evidence from host population genetics, viral genetics, DNA expression microarrays, and assays of lymphocyte function suggests that complex virus-host interactions and the host immune response play an important role in the pathogenesis of HAM/TSP. Especially, the efficiency of an individual's cytotoxic T-cell (CTL) response to HTLV-1 limits the HTLV-1 proviral load and the risk of HAM/TSP. This paper focuses on the recent advances in HAM/TSP research with the aim to identify the precise mechanisms of disease, in order to develop effective treatment and prevention.
\end{abstract}

\section{Introduction}

Human T-cell leukemia virus type-1 (HTLV-1) is a human retrovirus etiologically associated with adult T-cell leukemia (ATL) [1-3] and HTLV-1-associated myelopathy/tropical spastic paraparesis (HAM/TSP) $[4,5]$. HAM/TSP is a chronic progressive myelopathy characterized by spastic paraparesis, sphincter dysfunction, and mild sensory disturbance in the lower extremities [6]. Cases of HAM/TSP have been reported throughout the HTLV-1 endemic areas such as Southern Japan, the Caribbean, Central and South America, the Middle East, Melanesia, and equatorial regions of Africa [7]. Sporadic cases have also been described in nonendemic areas such as the United States and Europe, mainly in immigrants from an HTLV-1 endemic area. In contrast to HIV-1 infection, few with HTLV-1 develop disease: approximately $2 \%-3 \%$ of infected persons develop ATL [8] and other $0.25 \%-3.8 \%$ develop HAM/TSP [9-12], while the majority of infected individuals remain lifelong asymptomatic carriers (ACs). However, the ability to evaluate the individual risk of HTLV-1-associated diseases in each AC would make a significant clinical impact, especially in HTLV-1 endemic areas. During the last three decades since the discovery of HTLV-1 as the first pathogenic human retrovirus, advances in HTLV-1 research have helped us to understand the clinical features of HTLV-1 associated diseases, the virological properties of HTLV-1, and the importance of the viral, host, and environmental risk factors as well as the host immune response against HTLV1 infection. However, the precise mechanism of disease pathophysiology is still incompletely understood, and the treatment is still unsatisfactory, because good small-animal models for studying HTLV-1 infection and its associated diseases were unavailable until recently. In this paper, we summarize the recent developments of HTLV-1 research to try to identify more precisely the pathogenetic mechanisms 
of the disease in order to develop effective treatment and prevention.

\section{HTLV-1 Infection and Clinical Features of HAM/TSP}

2.1. Virological Aspects of HTLV-1. HTLV-1 is classified as a complex retrovirus in the genus Deltaretrovirus of the subfamily Orthoretrovirinae and infects 10-20 million people worldwide [13-15]. HTLV-1 can be transmitted through sexual contact [16], injection drug use [15], and breastfeeding from mother to child $[17,18]$. For over two decades, the investigation of HTLV-1-mediated pathogenesis has been focused on Tax, an HTLV-1 encoded viral oncoprotein, since Tax has been viewed as critical for leukemogenesis because of its pleiotropic effects on both viral and many cellular genes responsible for cell proliferation, genetic instability, dysregulation of the cell cycle, and apoptosis [19]. However, Tax expression is not detected in about $60 \%$ of freshly isolated samples from ATL cases [20]. In 2002, another regulatory protein encoded in the minus or antisense strand of the virus genome, named HTLV-1 basic leucine zipper factor (HBZ), was identified [21]. The spliced form of HBZ is expressed in all ATL [22] and HAM/TSP [23] cases, and its expression is strongly correlated with the HTLV1 proviral load (PVL) in HTLV-1-infected individuals and with disease severity in HAM/TSP patients [23]. Also, HBZ protein promotes proliferation of ATL cells and induces Tcell lymphomas in $\mathrm{CD}^{+} \mathrm{T}$ cells by transgenic expression, indicating the possible involvement of $\mathrm{HBZ}$ expression in the development of ATL $[22,24]$. Moreover, among the HTLV1 encoded viral genes, only the HBZ gene sequence remains intact, unaffected by nonsense mutations and deletion [25]. These findings indicate that HBZ expression is indispensable for proliferation and survival of ATL cells and HTLV-1 infected cells, and that Tax expression is not always necessary for the maintenance of ATL [26].

2.2. Clinical and Pathological Features of HAM/TSP. HAM/ TSP is a chronic progressive myelopathy characterized by spastic paraparesis, sphincter dysfunction, and mild sensory disturbance in the lower extremities [6]. In addition to neurological symptoms, some HAM/TSP cases also exhibit autoimmune-like disorders, such as uveitis, arthritis, Tlymphocyte alveolitis, polymyositis, and Sjögren syndrome [14]. Among ACs, the lifetime risk of developing HAM/TSP, which is different among different ethnic groups, ranges between $0.25 \%$ and $4 \%$. It has been reported that the annual incidence of HAM/TSP is higher among Jamaican subjects than among Japanese subjects (20 versus 3 cases/100,000 population), with a two to three times higher risk for women in both populations [9-12]. The period from initial HTLV-1 infection to the onset of HAM/TSP is assumed to range from months to decades, a shorter time than for ATL onset [11,31]. HAM/TSP occurs both in vertically infected individuals and in those who become infected later in life (i.e., through sexual contact [almost exclusively from male to female], intravenous drug use, contaminated blood transfusions, etc.). The mean age at onset is 43.8 years, and the frequency of HAM/TSP is higher in women than in men (the male to female ratio of occurrence is $1: 2.3$ ) [11].

Pathological analysis of HAM/TSP autopsy materials indicates that the disease affects the spinal cord, predominantly at the thoracic level $[27,32,33]$. Loss of myelin and axons in the lateral, anterior, and posterior columns is associated with perivascular and parenchymal lymphocytic infiltration with the presence of foamy macrophages, proliferation of astrocytes, and fibrillary gliosis. In the cases with active-chronic lesions in the spinal cord, perivascular inflammatory infiltration with similar composition of cell subsets was also seen in the brain [28]. The peripheral nerve pathology of HAM/TSP patients with sensory disturbance showed varying degrees of demyelination, remyelination, axonal degeneration, regeneration, and perineurial fibrosis $[29,30]$. The presence of atypical lymphocytes (so-called "flower cells") in peripheral blood and cerebrospinal fluid (CSF), a moderate pleocytosis, and raised protein content in CSF are typically found in HAM/TSP patients. Oligoclonal immunoglobulin bands in the CSF, raised concentrations of inflammatory markers such as neopterin, tumor necrosis factor (TNF)- $\alpha$, interleukin (IL)-6 and interferon (IFN)$\gamma$, and an increased intrathecal antibody $(\mathrm{Ab})$ synthesis specific for HTLV-1 antigens have also been described [34]. Clinical progression of HAM/TSP is associated with an increase in the proviral load in individual patients, and a high ratio of proviral loads in CSF cells/peripheral blood mononuclear cells (PBMCs) is also significantly associated with clinically progressive disease [35]. The clinical and pathological characteristics of HAM/TSP described above are shown in Table 1.

\section{Risk Factors for HAM/TSP}

3.1. Host Genetic. A previous population association study of 202 cases of HAM/TSP and 243 ACs in Kagoshima prefecture, HTLV-1 endemic Southern Japan, revealed that one of the major risk factors is the HTLV-1 PVL. The median PVL was more than ten times higher in HAM/TSP patients than in ACs, and a high PVL was also associated with an increased risk of progression to disease [36, 37]. A higher PVL in HAM/TSP patients than in ACs was observed in other endemic areas such as the Caribbean [38], South America [39], and the Middle East [40]. It was suggested that genetic factors such as the human leukocyte antigen (HLA) genotype are related to the high PVL in HAM/TSP patients and genetic relatives. In Southern Japan, possession of the HLA-class I genes HLA-A*02 and $\mathrm{Cw}^{*} 08$ was associated with a statistically significant reduction in both HTLV$1 \mathrm{PVL}$ and the risk of HAM/TSP, whereas possession of HLA-class I HLA-B*5401 and class II HLA-DRB1*0101 predisposes to HAM/TSP in the same population (Table 2) $[37,41]$. Since the function of class I HLA proteins is to present antigenic peptides to CTL, these results imply that individuals with HLA-A* 02 or HLA-Cw* 08 mount a particularly efficient CTL response against HTLV-1, which may therefore be an important determinant of HTLV-1 PVL and the risk of HAM/TSP. In fact, it has been reported that CTL spontaneously kills autologous HTLV-1-infected 
TABLE 1: Clinical and pathological characteristics of HAM/TSP.

\begin{tabular}{|c|c|c|}
\hline Clinical characteristics & & References \\
\hline Onset & Insidious, slowly progressive & {$[11]$} \\
\hline \multirow{3}{*}{ Major clinical symptoms } & Spastic paraparesis & \multirow{3}{*}[11]{} \\
\hline & Sphincter dysfunction & \\
\hline & Mild sensory disturbance in the lower extremities & \\
\hline \multirow{5}{*}{ Complications } & Uveitis & \multirow{5}{*}[14]{} \\
\hline & Arthritis & \\
\hline & T-lymphocyte alveolitis & \\
\hline & Polymyositis & \\
\hline & Sjögren syndrome & \\
\hline Mean age at onset & 43.8 years & {$[11]$} \\
\hline Male-to-female ratio & $1: 2.3$ (male $:$ female $)$ & [11] \\
\hline \multirow{2}{*}{ Laboratory data } & Positive anti-HTLV-1 antibody in both serum and CSF & \multirow{2}{*}[11]{} \\
\hline & Moderate pleocytosis and raised protein content in CSF & \\
\hline Pathological characteristics & & References \\
\hline \multirow[b]{2}{*}{ Spinal cord } & $\begin{array}{l}\text { Loss of myelin and axons in the lateral, anterior, and posterior } \\
\text { columns-predominantly at the thoracic level }\end{array}$ & \multirow{2}{*}[27]{} \\
\hline & $\begin{array}{l}\text { Perivascular and parenchymal lymphocytic infiltration with the presence of } \\
\text { foamy macrophages, proliferation of astrocytes, and fibrillary } \\
\text { gliosis-predominantly at the thoracic level }\end{array}$ & \\
\hline \multirow[b]{2}{*}{ Brain } & $\begin{array}{l}\text { Perivascular and parenchymal lymphocytic infiltration with the presence of } \\
\text { foamy macrophages, proliferation of astrocytes, and fibrillary gliosis }\end{array}$ & \multirow{2}{*}[28]{} \\
\hline & $\begin{array}{l}\text { Perivascular inflammatory infiltration and fibrosis only in the cases with } \\
\text { active-chronic lesions in the spinal cord. The composition of cell subsets was } \\
\text { similar both in the spinal cord and in the brain }\end{array}$ & \\
\hline Peripheral nerve & $\begin{array}{l}\text { Varying degrees of demyelination, remyelination, axonal degeneration, } \\
\text { regeneration, and perineurial fibrosis }\end{array}$ & {$[29,30]$} \\
\hline
\end{tabular}

cells ex vivo [42], granzymes and perforin are more highly expressed in individuals with a low PVL [43], and the lytic efficiency of the $\mathrm{CD} 8^{+} \mathrm{T}$ cell response, that is, the fraction of autologous HTLV-1-expressing cells eliminated per $\mathrm{CD}^{+}$ $\mathrm{T}$ cell per day, was inversely correlated with both PVL and the rate of spontaneous proviral expression [44]. These findings indicate that the CTL against HTLV-1 reduces PVL and risk of HAM/TSP. Moreover, using a combination of computational and experimental approaches, MacNamara et al. recently reported that a CTL response against $\mathrm{HBZ}$ restricted by protective HLA alleles such as HLA-A*02 or $\mathrm{CW}^{*} 08$, but not a response to the immunodominant protein Tax, determines the outcome of HTLV-1 infection [45].

Analysis of non-HLA host genetic factors by candidate gene approaches revealed that non-HLA gene polymorphisms also affect the risk of developing HAM/TSP (Table 2). For example, the TNF- $\alpha$ promoter-863 A allele [47] and the longer CA repeat alleles of matrix metalloproteinase (MMP)9 promoter [48] predisposed to HAM/TSP, whereas IL-10592 A [49], stromal-derived factor (SDF)-1 +801A, and IL-15 $+191 \mathrm{C}$ alleles [47] conferred protection against HAM/TSP. The polymorphisms in the MMP-9 and IL-10 promoters were each associated with differences in the HTLV-1 Taxmediated transcriptional activity of the respective gene [48, 49]. However, the contributions of these non-HLA genes to the pathogenesis of HAM/TSP are largely unknown, and these data have not yet been reproduced in different populations. Further candidate gene studies together with genomewide association studies in different ethnic populations in larger sample size may provide evidence for the association of non-HLA genes with HAM/TSP pathogenesis.

3.2. HTLV-1 Genotype and Genomic Integration Site. Although most studies of HTLV-1 genotype have reported no association between variants of HTLV-1 and the risk of HAM/TSP, Furukawa et al. reported the association between HTLV-1 tax gene variation and the risk of HAM/TSP [46]. The tax subgroup A, which belongs to cosmopolitan subtype A, was more frequently observed in HAM/TSP patients, and this association was independent of the protective effect of the HLA allele HLA-A*02. HLA-A*02 appeared to give protection against only one of the two prevalent sequence variants of HTLV-1, tax subgroup B which belongs to cosmopolitan subtype $\mathrm{B}$, but not against tax subgroup $\mathrm{A}$ in the Japanese population [46]. Interestingly, HLA$\mathrm{A}^{*} 02$ appeared not to give protection against infection with cosmopolitan subtype A in a population in Iran [40]. Moreover, the Iranian HTLV-1 strain has a Rex protein that is 20 amino acids longer than that of the Japanese strain that belongs to cosmopolitan subtype B. Experiments are now underway to compare the functions of these Rex proteins. 
TABLE 2: Host genetic and viral factors associated with the risk of HAM/TSP.

\begin{tabular}{|c|c|c|c|}
\hline Factor & Condition & Effect & Reference(s) \\
\hline \multirow{2}{*}{ Viral factors } & HTLV-1 tax subgroup A & Susceptible & {$[46]$} \\
\hline & Proviral load & Susceptible & {$[36]$} \\
\hline \multicolumn{4}{|l|}{ Host factors } \\
\hline \multirow{4}{*}{ HLA } & $\mathrm{A}^{*} 02$ & Protective & {$[37,41]$} \\
\hline & $\mathrm{Cw}^{*} 08$ & Protective & {$[41]$} \\
\hline & B*5401 & Susceptible & {$[41]$} \\
\hline & $\mathrm{DRB} 1 * 0101$ & Susceptible & {$[37]$} \\
\hline \multirow{5}{*}{ Non-HLA } & TNF- $\alpha$ promoter -863 A allele & Susceptible & {$[47]$} \\
\hline & longer CA repeat alleles of MMP-9 promoter & Susceptible & {$[48]$} \\
\hline & IL-10 promoter -592 A allele & Protective & {$[49]$} \\
\hline & SDF-1 promoter +801 A allele & Protective & {$[47]$} \\
\hline & IL-15 +191 C allele & Protective & {$[47]$} \\
\hline
\end{tabular}

Recently, to test whether the genomic integration site determines the abundance and the pathogenic potential of an HTLV-1-positive T-cell clone, Gillet et al. reported the results of high-throughput mapping and quantification of HTLV-1 proviral integration in the host genome [50]. They mapped $>91,000$ unique insertion sites (UISs) of the provirus from 61 HTLV-1-infected individuals in primary PBMCs and showed that a typical HTLV-1-infected host carries between 500 and 5000 UISs in $10 \mu \mathrm{g}$ of PBMC genomic DNA. They calculated an oligoclonality index (OCI) to quantify the clonality of HTLV-1-infected cells in vivo and found that the OCI did not distinguish between ACs and patients with HAM/TSP and that there was no correlation between OCI and HTLV-1PVL in either ACs or HAM/TSP patients. These results indicate that the higher PVL observed in patients with HAM/TSP was attributable to a larger number of UISs but not, as previously thought, from a difference in clonality. They also obtained evidence that the abundance of established HTLV1 clones is determined by genomic features of the host DNA flanking the provirus. Namely, HTLV-1 clonal expansion in vivo is favored by a proviral integration site near a region of host chromatin undergoing active transcription, or samesense transcriptional orientation of the provirus. Negative selection of infected clones, probably by CTLs during chronic infection, favors establishment of proviruses integrated in transcriptionally silenced DNA, and this selection is more efficient in ACs than in HAM/TSP, indicating the selection of HTLV-1-infected T-cell clones with low pathogenic potential.

\section{Immune Response to HTLV-1}

\subsection{Innate Immune Response}

4.1.1. Natural Killer (NK) Cells . Previous reports indicated that patients with HAM/TSP had both a lower frequency and a lower activity of NK cells (especially the $\mathrm{CD} 3^{+} \mathrm{CD} 16^{+}$ subset) than ACs although the results were not normalized with respect to PVL [51]. Since an important mechanism of induction of NK cell-mediated killing is recognition by the NK cell of a complex of the nonpolymorphic MHC molecule HLA-E bound to a peptide derived from the signal sequence of some other MHC class I molecules, a synthetic tetramer of HLA-E with the HLA-G signal sequence peptide was used to identify NK cells in HAM/TSP patients [52]. The results showed a significantly lower frequency of HLA-E tetramer-binding cells in HAM/TSP patients than ACs, and as in the earlier studies [51], this reduction in frequency was particularly notable in the $\mathrm{CD}^{+}$cells, whereas there was no significant difference in the frequency of HLA-E tetramer-binding $\mathrm{CD}^{-}$cells between patients with HAM/TSP and ACs [52]. Recent data also suggest that the frequency of invariant NKT (iNKT) cells in the peripheral blood of HAM/TSP patients is significantly decreased when compared with healthy subjects and/or ACs $[53,54]$. These findings indicate that the activity of the NK or NKT cell response was associated with the absence of HAM/TSP. Interestingly, a previous uncontrolled preliminary trial of treatment of HAM/TSP with fermented milk containing viable Lactobacillus casei strain Shirota resulted in a significant increase in NK cell activity, with improvements in clinical symptoms [55]. Thus, circulating NK and NKT cells might also play an important role in the disease progression and the pathogenesis of HAM/TSP. Recently, it has been reported that in addition to the previously described $\mathrm{CD} 8^{+}$ T-cell spontaneous proliferation [56], CD $56^{+}$NK cells also spontaneously proliferated in vitro, and spontaneous NK cell proliferation positively correlated with HTLV-1 PVL but not with the presence of HAM/TSP [57]. A hallmark of HTLV1 infection is the in vitro proliferation of PBMCs when cultured in the absence of exogenous antigen or mitogen, referred to as spontaneous lymphocyte proliferation (SLP), and in HAM/TSP patients, the levels of SLP reflect the severity of the disease $[58,59]$. Most of the high SLP observed in PBMCs from HAM/TSP patients is likely to be explained by a greater spontaneous expression of the provirus and consequently a greater proliferation of responding $\mathrm{CD} 8^{+} \mathrm{T}$ cells in culture [56]. The greater proviral expression may be partly attributable to the impaired function and decreased number of NK cells in HAM/TSP patients. Although further 
studies are required to clarify the role of NK cells in HTLV1 infection and HAM/TSP pathogenesis, NK cells might be also an interesting candidate for future immunotherapy.

4.1.2. Interferons. Type I interferon (IFN) is a key innate immune cytokine produced by cells in response to viral infection. The type I IFN response protects cells against invading viruses by inducing the expression of interferon-stimulated genes (ISGs), which execute the antiviral effects of IFN [60]. The ISGs then generate soluble factors including cytokines that activate adaptive immunity or directly inhibit the virus itself [61]. To date, IFN- $\alpha$ is not only one of the effective therapeutic agents for HAM/TSP, but also known as an only therapeutic agent whose efficacy was demonstrated in randomized placebo-controlled trials $[62,63]$. However, the therapeutic benefit is small, and IFN- $\alpha$ is not in general use in the treatment of HAM/TSP. The combination of the antiretroviral agent zidovudine (AZT) and IFN- $\alpha$ is also beneficial for overall survival in smoldering and chronic (i.e. indolent) ATL [64] although its efficacy has not yet been confirmed in well-designed prospective studies. It might be interesting to analyse which ISGs are changed in the course of IFN- $\alpha$ treatment and the functional role of ISGs as potential targets for therapy. In PBMCs of HTLV-1-infected individuals, the level of HTLV-1 mRNA is very low, and viral protein is not detectable, but these molecules are rapidly expressed after a short time in culture in vitro [42]. However, the mechanisms of this phenomenon are largely unknown. Recently, it has been reported that HTLV-1 expression in HTLV-1-infected T-cells is suppressed by stromal cells, that is epithelial cells and fibroblasts, in culture through type I IFNs [65]. Namely, HTLV-1 Gag protein expression was suppressed when contacted with stromal cells and restored when separated from the stromal cells. Although neutralizing antibodies against human IFN $\alpha / \beta$ receptor only partly abrogated this phenomenon, the results indicate that the innate immune system suppresses HTLV-1 expression in vitro and in vivo, at least through type I IFN.

4.2. Antibody Response to HTLV-1. In 2002, it was reported that antibodies that recognize HTLV-1 Tax protein can crossreact with a heterogenous-nuclear-riboprotein (hnRNP-) Al, suggesting intriguing evidence for antigen mimicry in HTLV-1 infection [66]. However, subsequent analysis using Japanese samples under fully masked conditions indicated that there was no difference in the incidence of anti-hnRNP A1 Abs between HAM/TSP and other neurological diseases [67]. It is unlikely that anti-Tax Ab explains the onset or initial tissue damage of HAM/TSP, as the host protein hnRNP-A1 is not confined to the central nervous system but is widely expressed [68] and is not normally accessible to $\mathrm{Ab}$ attack. Anti-Tax Ab might be associated with subsequent inflammation following initial tissue damage and disruption of blood brain barrier, which is probably caused by the antiviral immune responses to HTLV-1 and induces the release of autoantigens.

In HTLV-1 infection, HAM/TSP patients generally have a higher anti-HTLV-1 Ab titer than ACs with a similar HTLV-1 proviral load [69-71]. These anti-HTLV-1 Abs often include
IgM in both ACs and patients with HAM/TSP [70, 71]. These findings suggest that there was persistent expression of HTLV-1 proteins in vivo and the existence of an augmented humoral immune response to HTLV-1 in HAM/TSP patients. Although $\mathrm{Ab}$ responses to the immunodominant epitopes of the HTLV-1 envelope (Env) proteins were similar in all of three clinical groups (HAM/TSP, ATL, and ACs), reactivity to four Tax immunodominant epitopes was higher in HAM/TSP patients $(71 \%-93 \%)$ than in ATL patients $(4 \%-31 \%)$ or ACs $(27 \%-37 \%)$ [72]. Among these antiHTLV-1 antibodies, anti-EnvAb is particularly important since some anti-Env Abs have neutralizing activity against HTLV-1. Antisera raised against recombinant HTLV-1 Env polypeptides [73, 74], vaccinia virus containing HTLV-1 env gene $[75,76]$, immunization with neutralizing epitope peptides [77], and passive transfer of human IgG that has neutralizing activity $[78,79]$ were all shown to neutralize HTLV-1 infectivity. In HTLV-1 infection, the roles of HTLV1 neutralizing $\mathrm{Ab}$ in vivo are still largely unknown. It will be interesting to examine whether HTLV-1 neutralizing Ab titres correlate with disease status and PVL in infected individuals. Since the mutation rate of HTLV-1 provirus is significantly lower than HIV-1, passive immunization with human monoclonal $\mathrm{Ab}$ may be beneficial and effective method to prevent HTLV-1 infection.

4.3. Cytotoxic T-Lymphocyte (CTL) Response to HTLV-1. Previous reports indicated that the HTLV-1-specific $\mathrm{CD}^{+}$CTLs are typically abundant, chronically activated, and mainly targeted to the viral trans activator protein Tax [80]. Also, as already mentioned, the median PVL in PBMCs of HAM/TSP patients was more than ten times higher than that in ACs, and a high PVL was also associated with an increased risk of progression to disease $[36,37]$. Furthermore, HLA-A* 02 and $\mathrm{HLA}-\mathrm{Cw}^{*} 08$ genes were independently and significantly associated with a lower PVL and a lower risk of HAM/TSP $[37,41]$, and $\mathrm{CD}^{+} \mathrm{T}$ cells efficiently kill autologous Taxexpressing lymphocytes in fresh PBMCs in HTLV-1-infected individuals [42]. These data have raised the hypothesis that the class I-restricted CD8 ${ }^{+}$CTL response plays a critical part in limiting HTLV-1 replication in vivo and that genetically determined differences in the efficiency of the CTL response to HTLV-1 account for the risk for developing HAM/TSP. Indeed, as mentioned above (Section 3.1), MacNamara et al. [45] have shown that HLA class 1 alleles which strongly bind oligopeptides from the HBZ protein enable the host to make a more effective immune response against HTLV1 ; therefore, such individuals have a lower PVL and are more likely to be asymptomatic. Moreover, another recent report showed the presence of $\mathrm{HBZ}$-specific $\mathrm{CD} 4^{+}$and $\mathrm{CD} 8^{+}$cells in vivo in patients with HAM/TSP and in ACs and a significant association between the HBZ-specific $\mathrm{CD}^{+}$cell response and asymptomatic HTLV-1 infection [81]. These findings provide strong evidence to support the hypothesis of the crucial role of CTLs and also confirm the importance of HBZ for persistent infection.

Since the frequency of HTLV-1-specific $\mathrm{CD}^{+} \mathrm{T}$ cells was significantly higher in HAM/TSP patients than ACs $[82,83]$, and these cells have the potential to produce 
proinflammatory cytokines [84], there is a debate on the role of HTLV-1-specific-CD8 ${ }^{+} \mathrm{T}$ cells, that is, whether these cells contribute to the inflammatory and demyelinating processes of HAM/TSP, or whether the dominant effect of such cells in vivo is protective against disease. The analysis of gene expression profiles using microarrays in circulating $\mathrm{CD}^{+}$and $\mathrm{CD}^{+}$lymphocytes indicated that granzymes and perforin are more highly expressed in individuals with a low PVL [43], suggesting that a strong CTL response is associated with a low PVL and a low risk of HAM/TSP. Indeed, the lytic capacity of HTLV-1-specific CTL in patients with HAM/TSP and ACs, quantified by a CD107a mobilization assay, showed significantly lower CD107a staining in HTLV-1-specific CTL in HAM/TSP than ACs [85]. Recently, it has been reported that the high CTL avidity, which is closely associated with the lytic efficiency of CTL, correlates with low PVL and proviral gene expression [44], indicating that the efficient control of HTLV-1 in vivo depends on the quality of CTL, which determines the position of virus-host equilibrium and also the outcome of persistent HTLV-1 infection. However, two caveats must be made here. First, a protective role and a pathogenic role of CTLs are not mutually exclusive. Indeed, there are other examples of viral infections in which the virus-specific CTLs exert both beneficial (antiviral) and detrimental (inflammatory) effects, such as lymphocytic choriomeningitis virus (LCMV) infection in the mouse [86]. Second, it is difficult to separate cause and effect in analyzing the association between T-cell attributes and the efficiency of viral control in a persistent infection at equilibrium.

4.4. CD4 ${ }^{+}$Helper T-Cell Response to HTLV-1. Antiviral CD $4^{+}$ $\mathrm{T}$-cell responses are of central importance in driving $\mathrm{B}$ cell and $\mathrm{CD}^{+}$T-cell responses in vivo. The most common HTLV-1 antigen recognized by $\mathrm{CD}^{+}{ }^{-} \mathrm{T}$-cells is the Env protein $[87,88]$, in contrast with the immunodominance of Tax in the $\mathrm{CD}^{+} \mathrm{T}$-cell response [89-91]. At a similar PVL, patients with HAM/TSP had significantly increased frequency of virus-specific $\mathrm{CD}^{+}{ }^{+} \mathrm{T}$ cells compared to ACs $[88,92]$. The antiviral T-helper (Th) 1 phenotype is also dominant among HTLV-1-specific CD $4^{+}$T cells in both ACs and patients with HAM/TSP [93], and there is a higher frequency of IFN- $\gamma$, TNF- $\alpha$, and IL- 2 production by CD $4^{+}$ $\mathrm{T}$ cells in patients with HAM/TSP compared to AC of a similar PVL $[93,94]$. A role for $\mathrm{CD}^{+} \mathrm{T}$ cells in initiating and causing HAM/TSP is also consistent with the immunogenetic observations that the possession of HLA-DRB $1 * 0101$, which restricts the immunodominant epitope of HTLV-1 Env gp21, was associated with susceptibility to HAM/TSP in independent HTLV-1-infected populations in Southern Japan $[37,41]$ and Northeastern Iran [40]. Accordingly, a synthetic tetramer of $\mathrm{DRB} 1^{*} 0101$ and the immunodominant HTLV1 Env380-394 peptide was used to analyze Env-specific $\mathrm{CD}^{+}{ }^{+} \mathrm{T}$ cells directly ex vivo [92]. The results showed that the frequency of tetramer ${ }^{+} \mathrm{CD} 4^{+} \mathrm{T}$ cells was significantly higher in HAM/TSP patients than ACs with similar PVL. Furthermore, direct ex vivo analysis of tetramer ${ }^{+} \mathrm{CD} 4^{+} \mathrm{T}$ cells from two unrelated DRB1*0101-positive HAM/TSP patients indicated that certain T-cell receptors (TCRs) V $\beta$ s were utilized and antigen-specific amino acid motifs were identified in complementarity determining region (CDR) 3 from both patients. These results suggest that the observed increase in virus-specific CD4 ${ }^{+}$T cells in HAM/TSP patients, which may contribute to $\mathrm{CD}^{+}{ }^{+} \mathrm{T}$ cell-mediated antiviral immune responses and to an increased risk of HAM/TSP, was not simply due to the rapidly growing HTLV-1-infected $\mathrm{CD}^{+} \mathrm{T}$ cells but was the result of in vivo selection by specific MHC-peptide complexes, as observed in freshly isolated HLA-A*0201/Tax11-19 tetramer ${ }^{+} \mathrm{CD}^{+}$T cells [95] and muscle-infiltrating cells from HAM/TSP patients and HTLV-1-infected polymyositis patients [96].

4.5. Regulatory T Cells (Tregs) in HTLV-1 Infection. Regulatory $\mathrm{T}$ cells (Tregs) are important mediators of peripheral immune tolerance and also play an important role in chronic viral infections. In HTLV-1 infection, it has been reported that HTLV-1 preferentially and persistently infects $\mathrm{CD} 4^{+} \mathrm{CD} 25^{+}$lymphocytes in vivo [97], which contain the majority of the Foxp $3^{+}$Tregs [98]. In HAM/TSP patients, the frequency of Foxp $3^{+}$expression in $\mathrm{CD} 4{ }^{+} \mathrm{CD} 25^{+}$cells is lower than that in ACs and uninfected healthy controls $[97,99]$. This is probably due to the fact that CD25 is transcriptionally induced by HTLV-1 Tax [100], which may result in the reduced proportion of Foxp $3^{+}$cells in the $\mathrm{CD} 4{ }^{+} \mathrm{CD} 25^{+}$population in $\mathrm{HTLV}-1$-infected individuals, especially HAM/TSP patients. It is important to note that the $\mathrm{CD} 4^{+} \mathrm{CD} 25^{+}$population contains a mixture of Tregs and activated non-Tregs. Therefore, it is inappropriate to use CD25 as a marker of Tregs in HTLV-1 infection: the best current working definition of Treg phenotype is $\mathrm{CD} 4^{+}$Foxp $3^{+}$. Reports from different geographic regions indicate that the percentage of $\mathrm{CD}^{+} \mathrm{Foxp}^{+}$cells is higher in the HAM/TSP patients than in ACs [101-103]. It has been reported that the high frequency of $\mathrm{CD}^{+}{ }^{+} \mathrm{Foxp}^{+} \mathrm{T}$ cells in HTLV-1infected individuals is maintained by CCL22 produced by HTLV-1-infected PBMCs [104]. The frequency of HTLV-1negative $\mathrm{CD}^{+}{ }^{+} \mathrm{Foxp}^{+}$cells was positively correlated with the HTLV-1 proviral load [102, 105], and the CTL activity was negatively correlated with the frequency of HTLV-1-negative $\mathrm{CD}^{+}{ }^{+}$Foxp $^{+}$cells $[102]$, suggesting that $\mathrm{CD} 4^{+} \mathrm{Foxp}^{+}$Tregs may impair the CTL surveillance of HTLV-1. If this is the case, activity of $\mathrm{CD}^{+} \mathrm{Foxp}^{+}$cells may also determine the risk of developing HAM/TSP via increasing the HTLV-1 PVL.

4.6. Dendritic Cells (DCs). Dendritic cells are antigenpresenting cells which play a critical role in the regulation of the adaptive immune response. In HTLV-1 infection, it has been shown that the DCs from HAM/TSP patients were infected with HTLV-1 [106], and the development of $\mathrm{HAM} / \mathrm{TSP}$ is associated with rapid maturation of DCs [107]. As already mentioned, one of the hallmarks of HTLV-1 infection is the spontaneous lymphocyte proliferation (SLP). Interestingly, depletion of DCs from the HAM/TSP patient's PBMCs abolished SLP, whereas supplementing DCs restores proliferation [106]; supplementing B cells or macrophages had no effect. A DC-dependent mechanism of SLP was further supported by data showing that antibodies to MHC 


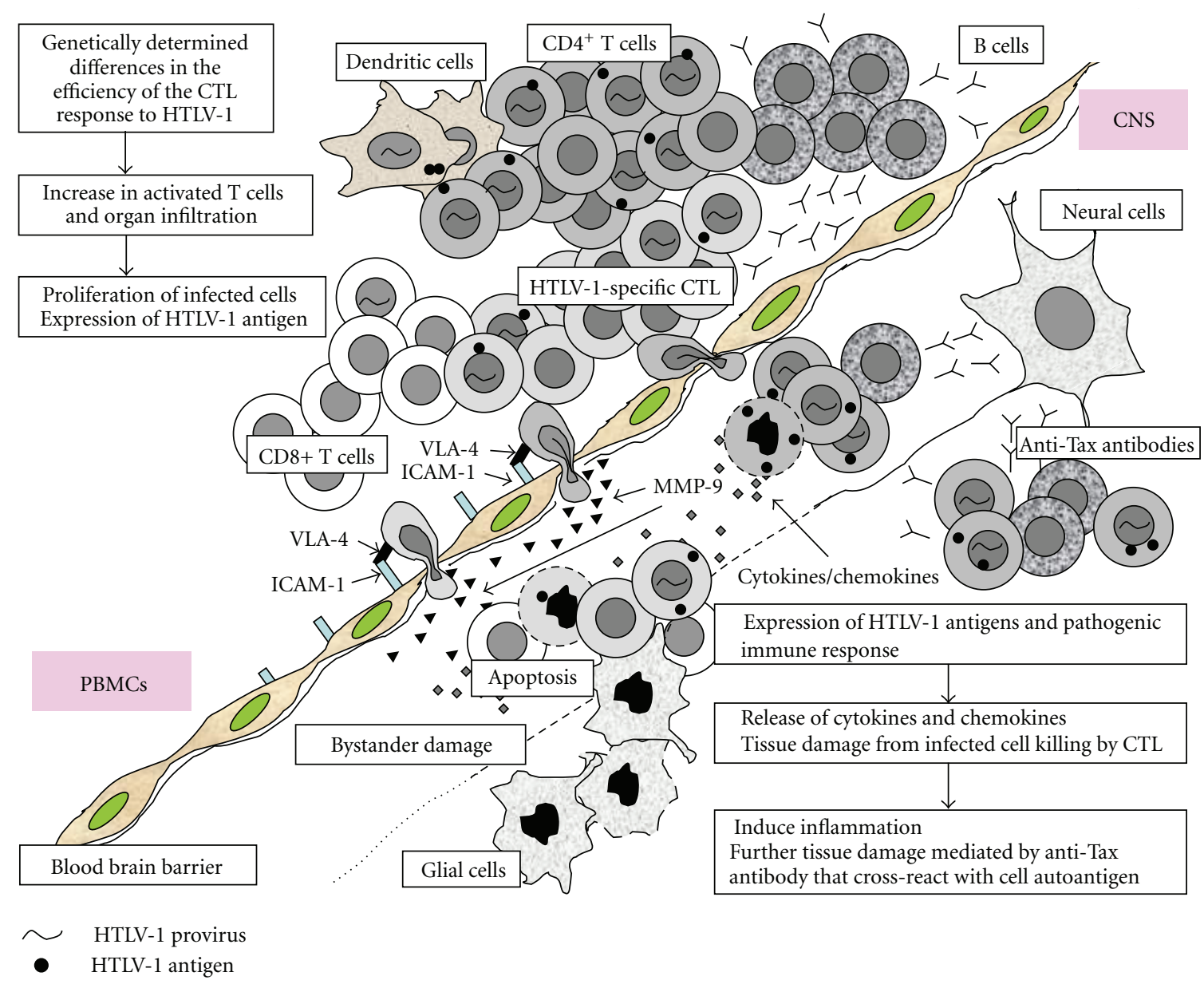

Figure 1: Hypothesis for the pathogenesis of human T-cell leukemia virus type-1 (HTLV-1) -associated myelopathy/tropical spastic paraparesis (HAM/TSP). Accumulating evidence suggests that the virus-host immunologic interactions play a pivotal role in HAM/TSP pathogenesis. Genetically determined less efficient CTL response against HTLV-1 may cause higher proviral load and antigen expression in infected individuals, which lead to activation and expansion of antigen-specific T-cell responses, subsequent induction of large amounts of proinflammatory cytokines and chemokines, and progression of HAM/TSP development. It is also possible that the immunoglobulin G specific to HTLV-1-Tax, which cross-react with heterogeneous nuclear ribonuclear protein-A1 (hnRNP-A1), is associated with subsequent inflammation following initial tissue damage.

class II, CD86, and CD58 can block SLP [108]. Recently, it has been demonstrated that both myeloid and plasmacytoid DCs are susceptible to infection with cell-free HTLV-1, and HTLV-1-infected DCs can rapidly transfer virus to autologous primary $\mathrm{CD} 4^{+} \mathrm{T}$ cells [109]. In addition, other groups have obtained evidence that HTLV-1 transmission from DCs to $\mathrm{T}$ cells was mediated primarily by DCSIGN [110], and DCs play a major part in generating and maintaining the Tax-specific $\mathrm{CD} 8^{+} \mathrm{T}$ cells both in vitro and in vivo [111]. Moreover, using transgenic mouse models that permit conditional transient depletion of $\mathrm{CD} 11 \mathrm{c}^{+}$ DCs, and a chimeric HTLV-1 that carries the envelope gene from Moloney murine leukemia virus, Rahman et al. demonstrated the critical role of DCs in their ability to mount both innate and adaptive immune responses during early cell-free HTLV-1 infection [112, 113]. Since HTLV-1 can impair the differentiation of monocytes into DCs [114], the interaction of DCs with HTLV-1 plays a central part in the persistence and pathogenesis of HTLV-1.

\section{Concluding Remarks}

As shown in Figure 1, accumulating evidence suggests that the host immune response, especially the CTL response, plays a critical role in determining the risk of HAM/TSP. A less efficient CTL response against HTLV-1 may cause a higher PVL and higher antigen expression in infected individuals, which in turn lead to activation and expansion of antigen-specific T-cell responses, subsequent induction of large amounts of proinflammatory cytokines and chemokines, and progression to HAM/TSP. Since HLA class 1 genotype determines only up to $50 \%$ of HAM/TSP risk in infected people [41], it is important to discover other factors that determine the efficiency of the CTL response 
to HTLV-1 and the outcome of HTLV-1 infection. Studies of the HTLV-1 receptor and DCs are also critical in the development of vaccine approaches to elicit cellular immune responses to key viral proteins such as Tax and Env to ablate HTLV-1-infected T cells. Newer approaches using genetically engineered and/or humanized mouse models for HTLV-1 infection will help to develop effective treatment and prevention of HAM/TSP in the future.

\section{Acknowledgments}

The authors thank the Ministry of Health, Labor and Welfare, Japan (Health Labour Sciences Research Grant), the Japan Society for the Promotion of Science (JSPS) (Grant-inAid for Scientific Research, ref. 21590512), and the Wellcome Trust (UK), for financial support.

\section{References}

[1] B. J. Poiesz, F. W. Ruscetti, A. F. Gazdar, P. A. Bunn, J. D. Minna, and R. C. Gallo, "Detection and isolation of type C retrovirus particles from fresh and cultured lymphocytes of a patient with cutaneous T-cell lymphoma," Proceedings of the National Academy of Sciences of the United States of America, vol. 77, no. 12, pp. 7415-7419, 1980.

[2] Y. Hinuma, K. Nagata, M. Hanaoka et al., "Adult T-cell leukemia: antigen in an ATL cell line and detection of antibodies to the antigen in human sera," Proceedings of the National Academy of Sciences of the United States of America, vol. 78, no. 10, pp. 6476-6480, 1981.

[3] M. Yoshida, M. Seiki, K. Yamaguchi, and K. Takatsuki, "Monoclonal integration of human T-cell leukemia provirus in all primary tumors of adult T-cell leukemia suggests causative role of human T-cell leukemia virus in the disease," Proceedings of the National Academy of Sciences of the United States of America, vol. 81, no. 8, pp. 2534-2537, 1984.

[4] M. Osame, K. Usuku, S. Izumo et al., "HTLV-I associated myelopathy, a new clinical entity," The Lancet, vol. 1, no. 8488, pp. 1031-1032, 1986.

[5] A. Gessain, F. Barin, J. C. Vernant et al., "Antibodies to human T-lymphotropic virus type-I in patients with tropical spastic paraparesis," The Lancet, vol. 2, no. 8452, pp. 407-410, 1985.

[6] M. Nakagawa, K. Nakahara, Y. Maruyama et al., "Therapeutic trials in 200 patients with HTLV-I-associated myelopathy/ tropical spastic paraparesis," Journal of NeuroVirology, vol. 2, no. 5, pp. 345-355, 1996.

[7] K. Verdonck, E. González, S. van Dooren, A. M. Vandamme, G. Vanham, and E. Gotuzzo, "Human T-lymphotropic virus 1: recent knowledge about an ancient infection," Lancet Infectious Diseases, vol. 7, no. 4, pp. 266-281, 2007.

[8] K. Tajima, "The 4th nation-wide study of adult T-cell leukemia/lymphoma (ATL) in Japan: estimates of risk of ATL and its geographical and clinical features," International Journal of Cancer, vol. 45, no. 2, pp. 237-243, 1990.

[9] M. Osame, R. Janssen, H. Kubota et al., "Nationwide survey of HTLV-I-asscociated myelopathy in Japan: association with blood transfusion," Annals of Neurology, vol. 28, no. 1, pp. 50-56, 1990.

[10] M. Hisada, S. O. Stuver, A. Okayama et al., "Persistent paradox of natural history of human T lymphotropic virus type I: parallel analyses of Japanese and Jamaican carriers," Journal of Infectious Diseases, vol. 190, no. 9, pp. 1605-1609, 2004.
[11] M. Nakagawa, S. Izumo, S. Ijichi et al., "HTLV-I-associated myelopathy: analysis of 213 patients based on clinical features and laboratory findings," Journal of Neurovirology, vol. 1, no. 1, pp. 50-61, 1995.

[12] A. Kramer, E. M. Maloney, O. S. C. Morgan et al., "Risk factors and cofactors for human T-cell lymphotropic virus type I (HTLV-I)-associated myelopathy/tropical spastic paraparesis (HAM/TSP) in Jamaica," American Journal of Epidemiology, vol. 142, no. 11, pp. 1212-1220, 1995.

[13] G. de The and R. Bomford, "An HTLV-I vaccine: why, how, for whom?" AIDS Research and Human Retroviruses, vol. 9, no. 5, pp. 381-386, 1993.

[14] T. Uchiyama, "Human T cell leukemia virus type I (HTLV-I) and human diseases," Annual Review of Immunology, vol. 15, pp. 15-37, 1997.

[15] F. A. Proietti, A. B. F. Carneiro-Proietti, B. C. Catalan-Soares, and E. L. Murphy, "Global epidemiology of HTLV-I infection and associated diseases," Oncogene, vol. 24, no. 39, pp. 60586068, 2005.

[16] D. F. Roucoux, B. Wang, D. Smith et al., "A prospective stud$\mathrm{y}$ of sexual transmission of human $\mathrm{T}$ lymphotropic virus (HTLV)-I and HTLV-II," Journal of Infectious Diseases, vol. 191, no. 9, pp. 1490-1497, 2005.

[17] S. Hino, K. Yamaguchi, and S. Katamine, "Mother-tochild transmission of human T-cell leukemia virus type-I," Japanese Journal of Cancer Research, vol. 76, no. 6, pp. 474480, 1985.

[18] K. Kinoshita, T. Amagasaki, and S. Hino, "Milk-borne transmission of HTLV-I from carrier mothers to their children," Japanese Journal of Cancer Research, vol. 78, no. 7, pp. 674680, 1987.

[19] S. J. Marriott and O. J. Semmes, "Impact of HTLV-I Tax on cell cycle progression and the cellular DNA damage repair response," Oncogene, vol. 24, no. 39, pp. 5986-5995, 2005.

[20] S. Takeda, M. Maeda, S. Morikawa et al., "Genetic and epigenetic inactivation of TAX gene in adult t-cell leukemia cells," International Journal of Cancer, vol. 109, no. 4, pp. 559$567,2004$.

[21] G. Gaudray, F. Gachon, J. Basbous, M. Biard-Piechaczyk, C. Devaux, and J. M. Mesnard, "The complementary strand of the human T-cell leukemia virus type 1 RNA genome encodes a bZIP transcription factor that down-regulates viral transcription," Journal of Virology, vol. 76, no. 24, pp. 1281312822, 2002.

[22] Y. Satou, J. I. Yasunaga, M. Yoshida, and M. Matsuoka, "HTLV-I basic leucine zipper factor gene mRNA supports proliferation of adult T cell leukemia cells," Proceedings of the National Academy of Sciences of the United States of America, vol. 103, no. 3, pp. 720-725, 2006.

[23] M. Saito, T. Matsuzaki, Y. Satou et al., "In vivo expression of the HBZ gene of HTLV-1 correlates with proviral load, inflammatory markers and disease severity in HTLV-1 associated myelopathy/tropical spastic paraparesis (HAM/TSP)," Retrovirology, vol. 6, article 19, 2009.

[24] Y. Satou, J.-I. Yasunaga, T. Zhao et al., "HTLV-1 bZIP factor induces T-cell lymphoma and systemic inflammation in vivo," PLoS Pathogens, vol. 7, no. 2, Article ID e1001274, 2011.

[25] J. Fan, M. Guangyong, K. Nosaka et al., "APOBEC3G generates nonsense mutations in human $\mathrm{T}$-cell leukemia virus type 1 proviral genomes in vivo," Journal of Virology, vol. 84, no. 14, pp. 7278-7287, 2010. 
[26] M. Matsuoka and K. T. Jeang, "Human T-cell leukemia virus type 1 (HTLV-1) and leukemic transformation: viral infectivity, Tax, HBZ and therapy," Oncogene, vol. 30, pp. 1379-1389, 2011.

[27] S. Izumo, F. Umehara, and M. Osame, "HTLV-I-associated myelopathy," Neuropathology, vol. 20, pp. S65-S68, 2000.

[28] M. M. Aye, E. Matsuoka, T. Moritoyo et al., "Histopathological analysis of four autopsy cases of HTLV-I-associated myelopathy/tropical spastic paraparesis: inflammatory changes occur simultaneously in the entire central nervous system," Acta Neuropathologica, vol. 100, no. 3, pp. 245-252, 2000.

[29] A. I. Bhigjee, P. L. A. Bill, C. A. Wiley et al., "Peripheral nerve lesions in HTLV-I associated myelopathy (HAM/TSP)," Muscle and Nerve, vol. 16, no. 1, pp. 21-26, 1993.

[30] T. Kiwaki, F. Umehara, Y. Arimura et al., "The clinical and pathological features of peripheral neuropathy accompanied with HTLV-I associated myelopathy," Journal of the Neurological Sciences, vol. 206, no. 1, pp. 17-21, 2003.

[31] S. Olindo, P. Cabre, A. Lézin et al., "Natural history of human T-lymphotropic virus 1-associated myelopathy: a 14-year follow-up study," Archives of Neurology, vol. 63, no. 11, pp. 1560-1566, 2006.

[32] Y. Iwasaki, "Pathology of chronic myelopathy associated with HTLV-I infection (HAM/TSP)," Journal of the Neurological Sciences, vol. 96, no. 1, pp. 103-123, 1990.

[33] A. Yoshioka, G. Hirose, Y. Ueda, Y. Nishimura, and K. Sakai, "Neuropathological studies of the spinal cord in early stage HTLV-I-associated myelopathy (HAM)," Journal of Neurology Neurosurgery and Psychiatry, vol. 56, no. 9, pp. 1004-1007, 1993.

[34] S. Jacobson, "Immunopathogenesis of human T cell lymphotropic virus type I-associated neurologic disease," Journal of Infectious Diseases, vol. 186, no. 2, pp. S187-S192, 2002.

[35] N. Takenouchi, Y. Yamano, K. Usuku, M. Osame, and S. Izumo, "Usefulness of proviral load measurement for monitoring of disease activity in individual patients with human T-lymphotropic virus type I-associated myelopathy/tropical spastic paraparesis," Journal of NeuroVirology, vol. 9, no. 1, pp. 29-35, 2003.

[36] M. Nagai, K. Usuku, W. Matsumoto et al., "Analysis of HTLV-I proviral load in $202 \mathrm{HAM} / \mathrm{TSP}$ patients and 243 asymptomatic HTLV-I carriers: high proviral load strongly predisposes to HAM/TSP," Journal of NeuroVirology, vol. 4, no. 6, pp. 586-593, 1998.

[37] K. J. M. Jeffery, K. Usuku, S. E. Hall et al., "HLA alleles determine human T-lymphotropic virus-I (HTLV-I) proviral load and the risk of HTLV-I-associated myelopathy," Proceedings of the National Academy of Sciences of the United States of America, vol. 96, no. 7, pp. 3848-3853, 1999.

[38] A. Manns, W. J. Miley, R. J. Wilks et al., "Quantitative proviral DNA and antibody levels in the natural history of HTLV-I infection," Journal of Infectious Diseases, vol. 180, no. 5, pp. 1487-1493, 1999.

[39] V. Adaui, K. Verdonck, I. Best et al., "SYBR Green-based quantitation of human T-lymphotropic virus type 1 proviral load in Peruvian patients with neurological disease and asymptomatic carriers: influence of clinical status, sex, and familial relatedness," Journal of NeuroVirology, vol. 12, no. 6, pp. 456-465, 2006.

[40] A. H. Sabouri, M. Saito, K. Usuku et al., "Differences in viral and host genetic risk factors for development of human T-cell lymphotropic virus type 1 (HTLV-1)-associated myelopathy/ tropical spastic paraparesis between Iranian and Japanese
HTLV-1-infected individuals," Journal of General Virology, vol. 86, no. 3, pp. 773-781, 2005.

[41] K. J. M. Jeffery, A. A. Siddiqui, M. Bunce et al., "The influence of HLA class I alleles and heterozygosity on the outcome of human T cell lymphotropic virus type I infection," Journal of Immunology, vol. 165, no. 12, pp. 7278-7284, 2000.

[42] E. Hanon, S. Hall, G. P. Taylor et al., "Abundant Tax protein expression in $\mathrm{CD}^{+} \mathrm{T}$ cells infected with human T-cell lymphotropic virus type I (HTLV-I) is prevented by cytotoxic T lymphocytes," Blood, vol. 95, no. 4, pp. 1386-1392, 2000.

[43] A. M. Vine, A. G. Heaps, L. Kaftantzi et al., "The role of CTLs in persistent viral infection: cytolytic gene expression in $\mathrm{CD}^{+}$lymphocytes distinguishes between individuals with a high or low proviral load of human $\mathrm{T}$ cell lymphotropic virus type," Journal of Immunology, vol. 173, no. 8, pp. 51215129, 2004.

[44] T. Kattan, A. MacNamara, A. G. Rowan et al., "The avidity and lytic efficiency of the CTL response to HTLV-11," Journal of Immunology, vol. 182, no. 9, pp. 5723-5729, 2009.

[45] A. MacNamara, A. Rowan, S. Hilburn et al., "HLA class I binding of HBZ determines outcome in HTLV-1 infection," PLoS Pathogens, vol. 6, no. 9, Article ID e01117, 2010.

[46] Y. Furukawa, M. Yamashita, K. Usuku, S. Izumo, M. Nakagawa, and M. Osame, "Phylogenetic subgroups of human T cell lymphotropic virus (HTLV) type I in the tax gene and their association with different risks for HTLV-I-associated myelopathy/tropical spastic paraparesis," Journal of Infectious Diseases, vol. 182, no. 5, pp. 1343-1349, 2000.

[47] A. M. Vine, A. D. Witkover, A. L. Lloyd et al., "Polygenic control of human T lymphotropic virus type I (HTLV-I) provirus load and the risk of HTLV-I-associated myelopathy/tropical spastic paraparesis," Journal of Infectious Diseases, vol. 186, no. 7, pp. 932-939, 2002.

[48] D. Kodama, M. Saito, W. Matsumoto et al., "Longer dinucleotide repeat polymorphism in matrix metalloproteinase9 (MMP-9) gene promoter which correlates with higher HTLV-I Tax mediated transcriptional activity influences the risk of HTLV-I associated myelopathy/tropical spastic paraparesis (HAM/TSP)," Journal of Neuroimmunology, vol. 156, no. 1-2, pp. 188-194, 2004.

[49] A. H. Sabouri, M. Saito, A. L. Lloyd et al., "Polymorphism in the interleukin-10 promoter affects both provirus load and the risk of human $\mathrm{T}$ lymphotropic virus type I-associated myelopathy/tropical spastic paraparesis," Journal of Infectious Diseases, vol. 190, no. 7, pp. 1279-1285, 2004.

[50] N. A. Gillet, N. Malani, A. Melamed et al., "The host genomic environment of the provirus determines the abundance of HTLV-1-infected T-cell clones," Blood, vol. 117, no. 11, pp. 3113-3122, 2011.

[51] F. Yu, Y. Itoyama, K. Fujihara, and I. Goto, "Natural killer (NK) cells in HTLV-I-associated myelopathy/tropical spastic prapareses-decrease in NK cell subset populations and activity in HTLV-I seropositive individuals," Journal of Neuroimmunology, vol. 33, no. 2, pp. 121-128, 1991.

[52] M. Saito, V. M. Braud, P. Goon et al., "Low frequency of CD94/NKG2A ${ }^{+}$T lymphocytes in patients with HTLV-1associated myelopathy/tropical spastic paraparesis, but not in asymptomatic carriers," Blood, vol. 102, no. 2, pp. 577-584, 2003.

[53] K. Azakami, T. Sato, N. Araya et al., "Severe loss of invariant NKT cells exhibiting anti-HTLV-1 activity in patients with HTLV-1-associated disorders," Blood, vol. 114, no. 15, pp. 3208-3215, 2009. 
[54] L. C. Ndhlovu, J. E. Snyder-Cappione, K. I. Carvalho et al., "Lower numbers of circulating natural killer $\mathrm{T}(\mathrm{NK} \mathrm{T})$ cells in individuals with human T lymphotropic virus type 1 (HTLV1) associated neurological disease," Clinical and Experimental Immunology, vol. 158, no. 3, pp. 294-299, 2009.

[55] T. Matsuzaki, M. Saito, K. Usuku et al., "A prospective uncontrolled trial of fermented milk drink containing viable Lactobacillus casei strain Shirota in the treatment of HTLV1 associated myelopathy/tropical spastic paraparesis," Journal of the Neurological Sciences, vol. 237, no. 1-2, pp. 75-81, 2005.

[56] J. A. Sakai, M. Nagai, M. B. Brennan, C. A. Mora, and S. Jacobson, "In vitro spontaneous lymphoproliferation in patients with human T-cell lymphotropic virus type Iassociated neurologic disease: predominant expansion of $\mathrm{CD}^{+} \mathrm{T}$ cells," Blood, vol. 98, no. 5, pp. 1506-1511, 2001.

[57] P. J. Norris, D. F. Hirschkorn, D. A. Devita, T. H. Lee, and E. L. Murphy, "Human T cell leukemia virus type 1 infection drives spontaneous proliferation of natural killer cells," Virulence, vol. 1, no. 1, pp. 19-28, 2010.

[58] Y. Itoyama, S. Minato, J. Kira et al., "Spontaneous proliferation of peripheral blood lymphocytes increased in patients with HTLV-I-associated myelopathy," Neurology, vol. 38, no. 8, pp. 1302-1307, 1988.

[59] S. Ijichi, N. Eiraku, M. Osame et al., "In vitro modulation of lymphocyte proliferation by prednisolone and interferon$\alpha$ in patients with HTLV-I-associated myelopathy (HAM)," Journal of Neuroimmunology, vol. 23, no. 2, pp. 175-178, 1989.

[60] C. E. Samuel, "Antiviral actions of interferons," Clinical Microbiology Reviews, vol. 14, no. 4, pp. 778-809, 2001.

[61] S. Y. Liu, D. J. Sanchez, and G. Cheng, "New developments in the induction and antiviral effectors of type I interferon," Current Opinion in Immunology, vol. 23, pp. 57-64, 2011.

[62] Y. Kuroda, K. Kurohara, F. Fujiyama et al., "Systemic interferon-alpha in the treatment of HTLV-I-associated myelopathy," Acta Neurologica Scandinavica, vol. 86, no. 1, pp. 82-86, 1992.

[63] S. Izumo, I. Goto, Y. Itoyama et al., "Interferon-alpha is effective in HTLV-I-associated myelopathy: a multicenter, randomized, double-blind, controlled trial," Neurology, vol. 46, no. 4, pp. 1016-1021, 1996.

[64] A. Bazarbachi, Y. Plumelle, J. Carlos Ramos et al., "Metaanalysis on the use of zidovudine and interferon-alfa in adult T-cell leukemia/lymphoma showing improved survival in the leukemic subtypes," Journal of Clinical Oncology, vol. 28, no. 27, pp. 4177-4183, 2010.

[65] S. Kinpara, A. Hasegawa, A. Utsunomiya et al., "Stromal cellmediated suppression of human T-cell leukemia virus type 1 expression in vitro and in vivo by type I interferon," Journal of Virology, vol. 83, no. 10, pp. 5101-5108, 2009.

[66] M. C. Levin, S. M. Lee, F. Kalume et al., "Autoimmunity due to molecular mimicry as a cause of neurological disease," Nature Medicine, vol. 8, no. 5, pp. 509-513, 2002.

[67] M. Yukitake, E. Sueoka, N. Sueoka-Aragane et al., "Significantly increased antibody response to heterogeneous nuclear ribonucleoproteins in cerebrospinal fluid of multiple sclerosis patients but not in patients with human T-lymphotropic virus type I-associated myelopathy/tropical spastic paraparesis," Journal of NeuroVirology, vol. 14, no. 2, pp. 130-135, 2008.

[68] G. Dreyfuss, M. J. Matunis, S. Piñol-Roma, and C. G. Burd, "hnRNP proteins and the biogenesis of mRNA," Annual Review of Biochemistry, vol. 62, pp. 289-321, 1993.

[69] S. Ishihara, A. Okayama, S. Stuver et al., "Association of HTLV-I antibody profile of asymptomatic carriers with proviral DNA levels of peripheral blood mononuclear cells," Journal of Acquired Immune Deficiency Syndromes, vol. 7, no. 2, pp. 199-203, 1994.

[70] J. Kira, M. Nakamura, T. Sawada et al., "Antibody titers to HTLV-I-p40(tax) protein and gag-env hybrid protein in HTLV-I-associated myelopathy/tropical spastic paraparesis: correlation with increased HTLV-I proviral DNA load," Journal of the Neurological Sciences, vol. 107, no. 1, pp. 98-104, 1991.

[71] K. Nagasato, T. Nakamura, S. Shirabe et al., "Presence of serum anti-human T-lymphotropic virus type I (HTLV-I) IgM antibodies means persistent active replication of HTLV-I in HTLV-I-associated myelopathy," Journal of the Neurological Sciences, vol. 103, no. 2, pp. 203-208, 1991.

[72] R. B. Lal, C. Z. Giam, J. E. Coligan, and D. L. Rudolph, "Differential immune responsiveness to the immunodominant epitopes of regulatory proteins (tax and rex) in human $\mathrm{T}$ cell lymphotropic virus type I-associated myelopathy," Journal of Infectious Diseases, vol. 169, no. 3, pp. 496-503, 1994.

[73] T. Kiyokawa, H. Yoshikura, and S. Hattori, "Envelope proteins of human T-cell leukemia virus: expression in Escherichia coli and its application to studies of env gene functions," Proceedings of the National Academy of Sciences of the United States of America, vol. 81, no. 19, pp. 6202-6206, 1984.

[74] H. Nakamura, M. Hayami, Y. Ohta et al., "Protection of cynomolgus monkeys against infection by human T-cell leukemia virus type-I by immunization with viral env gene products produced in Escherichia coli," International Journal of Cancer, vol. 40, no. 3, pp. 403-407, 1987.

[75] H. Shida, T. Tochikura, T. Sato et al., "Effect of the recombinant vaccinia viruses that express HTLV-I envelope gene on HTLV-I infection," The EMBO Journal, vol. 6, no. 11, pp. 3379-3384, 1987.

[76] E. Hakoda, H. Machida, Y. Tanaka et al., "Vaccination of rabbits with recombinant vaccinia virus carrying the envelope gene of human T-cell lymphotropic virus type 1," International Journal of Cancer, vol. 60, no. 4, pp. 567-570, 1995.

[77] Y. Tanaka, R. Tanaka, E. Terada et al., "Induction of antibody responses that neutralize human T-cell leukemia virus type I infection in vitro and in vivo by peptide immunization," Journal of Virology, vol. 68, no. 10, pp. 6323-6331, 1994.

[78] Y. Tanaka, K. Ishii, T. Sawada et al., "Prophylaxis against a Melanesian variant of human T-lymphotropic virus type I (HTLV-I) in rabbits using HTLV-I immune globulin from asymptomatically infected Japanese carriers," Blood, vol. 82, no. 12, pp. 3664-3667, 1993.

[79] N. Murata, E. Hakoda, H. Machida et al., "Prevention of human $\mathrm{T}$ cell lymphotropic virus type I infection in Japanese macaques by passive immunization," Leukemia, vol. 10, no. 12, pp. 1971-1974, 1996.

[80] C. R. M. Bangham, “The immune response to HTLV-I,” Current Opinion in Immunology, vol. 12, no. 4, pp. 397-402, 2000.

[81] S. Hilburn, A. Rowan, M.-A. Demontis et al., "In vivo expression of human T-lymphotropic virus type 1 basic leucine-zipper protein generates specific CD8+ and CD4+ Tlymphocyte responses that correlate with clinical outcome," Journal of Infectious Diseases, vol. 203, no. 4, pp. 529-536, 2011.

[82] T. F. Greten, J. E. Slansky, R. Kubota et al., "Direct visualization of antigen-specific T cells: HTLV-1 Tax11-19-specific $\mathrm{CD}^{+} \mathrm{T}$ cells are activated in peripheral blood and accumulate in cerebrospinal fluid from HAM/TSP patients," 
Proceedings of the National Academy of Sciences of the United States of America, vol. 95, no. 13, pp. 7568-7573, 1998.

[83] M. Nagai, R. Kubota, T. F. Greten, J. P. Schneck, T. P. Leist, and $\mathrm{S}$. Jacobson, "Increased activated human T cell lymphotropic virus type I (HTLV-I) Tax11-19-specific memory and effector $\mathrm{CD}^{+}$cells in patients with HTLV-I-associated myelopathy/tropical spastic paraparesis: correlation with HTLV-I provirus load," Journal of Infectious Diseases, vol. 183, no. 2, pp. 197-205, 2001.

[84] R. Kubota, T. Kawanishi, H. Matsubara, A. Manns, and S. Jacobson, "Demonstration of human T lymphotropic virus type I (HTLV-I) tax-specific CD8 ${ }^{+}$lymphocytes directly in peripheral blood of HTLV-I-associated myelopathy/tropical spastic paraparesis patients by intracellular cytokine detection," Journal of Immunology, vol. 161, no. 1, pp. 482-488, 1998.

[85] A. H. Sabouri, K. Usuku, D. Hayashi et al., "Impaired function of human T-lymphotropic virus type 1 (HTLV-1) specific CD8 ${ }^{+} \mathrm{T}$ cells in HTLV-1 associated neurologic disease," Blood, vol. 112, no. 6, pp. 2411-2420, 2008.

[86] P. Klenerman and R. M. Zinkernagel, "What can we learn about human immunodeficiency virus infection from a study of lymphocytic choriomeningitis virus?" Immunological Reviews, vol. 159, pp. 5-16, 1997.

[87] B. Kitze, K. Usuku, Y. Yamano et al., "Human CD4+ T lymphocytes recognize a highly conserved epitope of human $\mathrm{T}$ lymphotropic virus type 1 (HTLV-1) env gp 21 restricted by HLA DRB1*0101," Clinical and Experimental Immunology, vol. 111, no. 2, pp. 278-285, 1998.

[88] P. K. C. Goon, T. Igakura, E. Hanon et al., "Human T cell lymphotropic virus type I (HTLV-I)-Specific CD4 ${ }^{+}$T Cells: immunodominance hierarchy and preferential infection with HTLV-I," Journal of Immunology, vol. 172, no. 3, pp. 17351743, 2004.

[89] M. Kannagi, S. Harada, I. Maruyama et al., "Predominant recognition of human T cell leukemia virus type I (HTLV-I) pX gene products by human $\mathrm{CD}^{+}$cytotoxic T cells directed against HTLV-I-infected cells," International Immunology, vol. 3, no. 8, pp. 761-767, 1991.

[90] S. Jacobson, H. Shida, D. E. McFarlin, A. S. Fauci, and S. Koenig, "Circulating $\mathrm{CD}^{+}$cytotoxic $\mathrm{T}$ lymphocytes specific for HTLV-I pX in patients with HTLV-I associated neurological disease," Nature, vol. 348, no. 6298, pp. 245-248, 1990.

[91] P. K. C. Goon, A. Biancardi, N. Fast et al., "Human T cell lymphotropic virus (HTLV) type-1-specific $\mathrm{CD}^{+} \mathrm{T}$ cells: frequency and immunodominance hierarchy," Journal of Infectious Diseases, vol. 189, no. 12, pp. 2294-2298, 2004.

[92] H. Nose, R. Kubota, N. P. Seth et al., "Ex vivo analysis of human $\mathrm{T}$ lymphotropic virus type 1 -specific $\mathrm{CD} 4^{+}$cells by use of a major histocompatibility complex class II tetramer composed of a neurological disease-susceptibility allele and its immunodominant peptide," Journal of Infectious Diseases, vol. 196, no. 12, pp. 1761-1772, 2007.

[93] P. K. C. Goon, E. Hanon, T. Igakura et al., "High frequencies of Th1-type $\mathrm{CD}^{+} \mathrm{T}$ cells specific to HTLV-1 Env and Tax proteins in patients with HTLV-1-associated myelopathy/ tropical spastic paraparesis," Blood, vol. 99, no. 9, pp. 33353341, 2002.

[94] P. K. C. Goon, T. Igakura, E. Hanon et al., "High circulating frequencies of tumor necrosis factor alpha- and interleukin2 -secreting human T-lymphotropic virus type 1 (HTLV-1)specific $\mathrm{CD}^{+} \mathrm{T}$ cells in patients with HTLV-1-associated neurological disease," Journal of Virology, vol. 77, no. 17, pp. 9716-9722, 2003.
[95] M. Saito, G. P. Taylor, A. Saito et al., "In vivo selection of T-cell receptor junctional region sequences by HLA-A2 human T-cell lymphotropic virus type 1 Tax11-19 peptide complexes," Journal of Virology, vol. 75, no. 2, pp. 1065-1071, 2001.

[96] M. Saito, I. Higuchi, A. Saito et al., "Molecular analysis of $\mathrm{T}$ cell clonotypes in muscle-infiltrating lymphocytes from patients with human T lymphotropic virus type 1 polymyositis," Journal of Infectious Diseases, vol. 186, no. 9, pp. 12311241, 2002.

[97] Y. Yamano, N. Takenouchi, H. C. Li et al., "Virus-induced dysfunction of $\mathrm{CD} 4{ }^{+} \mathrm{CD} 25^{+} \mathrm{T}$ cells in patients with HTLV-Iassociated neuroimmunological disease," Journal of Clinical Investigation, vol. 115, no. 5, pp. 1361-1368, 2005.

[98] S. Sakaguchi, M. Ono, R. Setoguchi et al., "Foxp $3^{+}$CD $25^{+}$ $\mathrm{CD}^{+}$natural regulatory $\mathrm{T}$ cells in dominant self-tolerance and autoimmune disease," Immunological Reviews, vol. 212, pp. 8-27, 2006.

[99] U. Oh, C. Grant, C. Griffith, K. Fugo, N. Takenouchi, and S. Jacobson, "Reduced Foxp3 protein expression is associated with inflammatory disease during human T lymphotropic virus type 1 infection," Journal of Infectious Diseases, vol. 193, no. 11, pp. 1557-1566, 2006.

[100] J. Inoue, M. Seiki, T. Taniguchi, S. Tsuru, and M. Yoshida, "Induction of interleukin 2 receptor gene expression by $\mathrm{p} 40 \mathrm{x}$ encoded by human T-cell leukemia virus type 1," The EMBO Journal, vol. 5, no. 11, pp. 2883-2888, 1986.

[101] D. Hayashi, R. Kubota, N. Takenouchi et al., "Reduced Foxp3 expression with increased cytomegalovirus-specific CTL in HTLV-I-associated myelopathy," Journal of Neuroimmunology, vol. 200, no. 1-2, pp. 115-124, 2008.

[102] F. Toulza, A. Heaps, Y. Tanaka, G. P. Taylor, and C. R. M. Bangham, "High frequency of $\mathrm{CD}^{+} \mathrm{FoxP}^{+}$cells in HTLV1 infection: inverse correlation with HTLV-l-specific CTL response," Blood, vol. 111, no. 10, pp. 5047-5053, 2008.

[103] I. Best, G. López, K. Verdonck et al., "IFN- $\beta$ production in response to Tax 161-233, and frequency of CD4 ${ }^{+}$Foxp $3^{+}$and Lin- HLA-DRhigh CD $123^{+}$cells, discriminate HAM/TSP patients from asymptomatic HTLV-1-carriers in a Peruvian population," Immunology, vol. 128, no. 1, pp. e777-e786, 2009.

[104] F. Toulza, K. Nosaka, Y. Tanaka et al., "Human T-lymphotropic virus type 1-induced CC chemokine ligand 22 maintains a high frequency of functional FoxP $3^{+}$regulatory T cells," Journal of Immunology, vol. 185, no. 1, pp. 183-189, 2010.

[105] D. Hayashi, R. Kubota, N. Takenouchi et al., "Accumulation of human T-lymphotropic virus type I (HTLV-I)-infected cells in the cerebrospinal fluid during the exacerbation of HTLV-I-associated myelopathy," Journal of NeuroVirology, vol. 14, no. 5, pp. 459-463, 2008.

[106] S. E. Macatonia, J. K. Cruickshank, P. Rudge, and S. C. Knight, "Dendritic cells from patients with tropical spastic paraparesis are infected with HTLV-1 and stimulate autologous lymphocyte proliferation," AIDS Research and Human Retroviruses, vol. 8, no. 9, pp. 1699-1706, 1992.

[107] M. Makino, A. Utsunomiya, Y. Maeda, S. Shimokubo, S. Izumo, and M. Baba, "Association of CD40 ligand expression on HTLV-I-infected $\mathrm{T}$ cells and maturation of dendritic cells," Scandinavian Journal of Immunology, vol. 54, no. 6, pp. 574-581, 2001.

[108] M. Makino, M. Azuma, S.-I. Wakamatsu et al., "Marked suppression of $\mathrm{T}$ cells by a benzothiophene derivative in patients with human T-lymphotropic virus type I-associated 
myelopathy/tropical spastic paraparesis," Clinical and Diagnostic Laboratory Immunology, vol. 6, no. 3, pp. 316-322, 1999.

[109] K. S. Jones, C. Petrow-Sadowski, Y. K. Huang, D. C. Bertolette, and F. W. Ruscetti, "Cell-free HTLV-1 infects dendritic cells leading to transmission and transformation of $\mathrm{CD}^{+} \mathrm{T}$ cells," Nature Medicine, vol. 14, no. 4, pp. 429-436, 2008.

[110] P. Jain, S. L. Manuel, Z. K. Khan, J. Ahuja, K. Quann, and B. Wigdahl, "DC-SIGN mediates cell-free infection and transmission of human T-cell lymphotropic virus type 1 by dendritic cells," Journal of Virology, vol. 83, no. 21, pp. 1090810921, 2009.

[111] S. L. Manuel, T. D. Schell, E. Acheampong, S. Rahman, Z. K. Khan, and P. Jain, "Presentation of human T cell leukemia virus type 1 (HTLV-1) Tax protein by dendritic cells: the underlying mechanism of HTLV-1-associated neuroinflammatory disease," Journal of Leukocyte Biology, vol. 86, no. 5, pp. 1205-1216, 2009.

[112] S. Rahman, S. L. Manuel, Z. K. Khan et al., "Depletion of dendritic cells enhances susceptibility to cell-free infection of human $\mathrm{T}$ cell leukemia virus type 1 in CD11c-diphtheria toxin receptor transgenic mice," Journal of Immunology, vol. 184, no. 10, pp. 5553-5561, 2010.

[113] S. Rahman, Z. K. Khan, B. Wigdahl, S. R. Jennings, F. Tangy, and P. Jain, "Murine FLT3 ligand-derived dendritic cellmediated early immune responses are critical to controlling cell-free human T cell leukemia virus type 1 infection," Journal of Immunology, vol. 186, no. 1, pp. 390-402, 2011.

[114] C. R. Nascimento, M. A. Lima, M. J. D. A. Serpa, O. Espindola, A. C. C. Leite, and J. Echevarria-Lima, "Monocytes from HTLV-1-infected patients are unable to fully mature into dendritic cells," Blood, vol. 117, no. 2, pp. 489-499, 2011. 


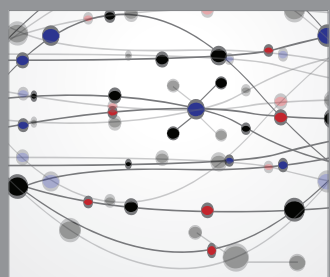

The Scientific World Journal
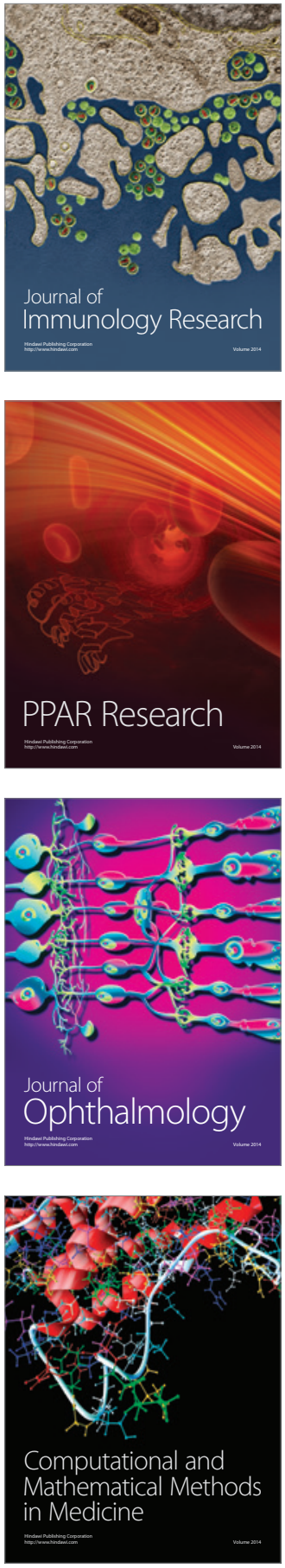

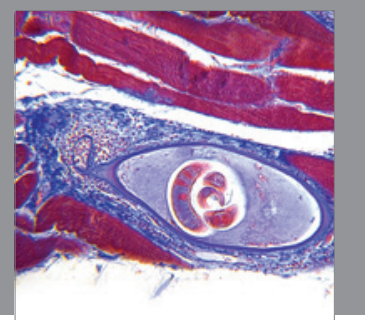

Gastroenterology

Research and Practice
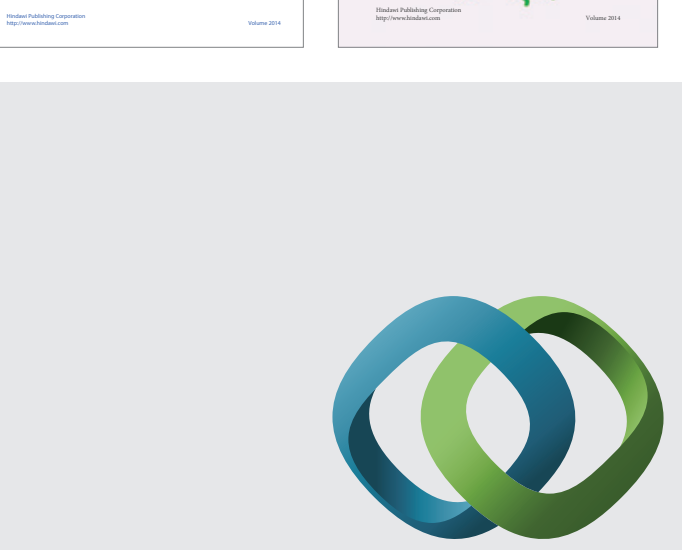

\section{Hindawi}

Submit your manuscripts at

http://www.hindawi.com
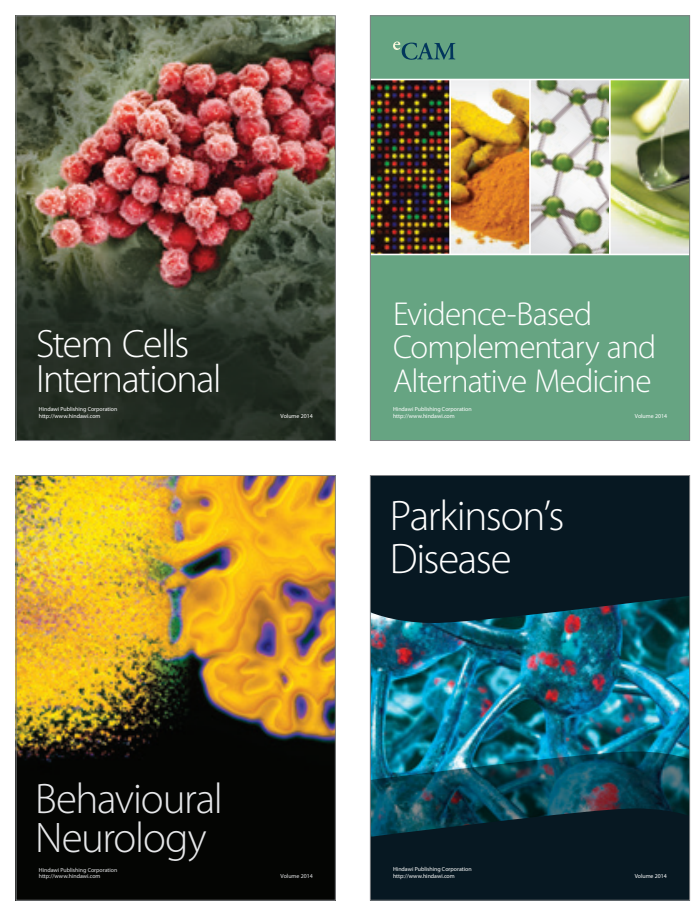

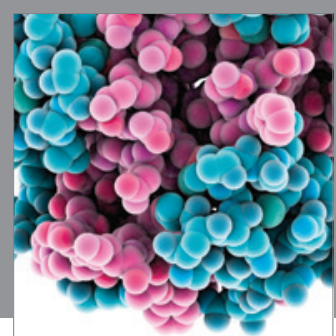

Journal of
Diabetes Research

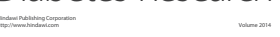

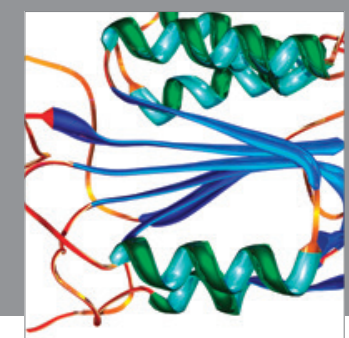

Disease Markers
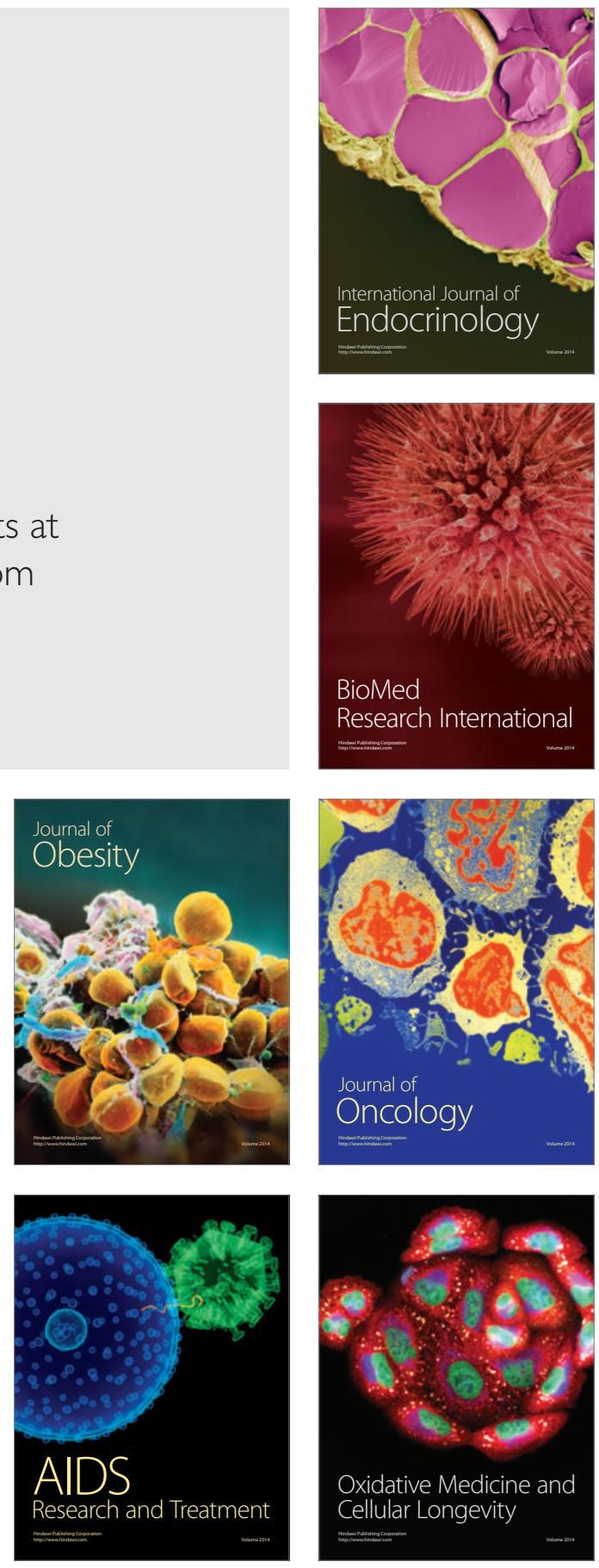